\title{
Assessing the Contemporary Issues of Countering Transnational Crime*
}

\author{
Ivan Volodimirovich Kubariev ${ }^{1}$, Yevgen Barash², Valeriy Dmytrovych \\ Pcholkin $^{3}$, Olena Ivanivna Pluzhnik ${ }^{4}$ \\ ${ }^{1}$ Institute of the Ministry of Internal Affairs of Ukraine, ${ }^{2}$ National Academy of \\ Internal Affairs Ukraine, ${ }^{3}$ Kharkiv National University of Internal Affairs, \\ ${ }^{4}$ Odessa State University of Internal Affairs Ukraine
}

\begin{abstract}
Crimes are always considered as inevitable in every given society operating under an organized system of operation. Sometimes this crime has to cross borders constituting huge threat to country sovereignty and integrity. With all this in place, States are usually confronted in establishing possible forms and methods of combating the so called transnational crimes. Specific examples of successful experience of developed countries, such as the United States, Canada and Western European countries, are analyzed. The author's definitions of the terms "transnational crime", "method of combating transnational crime" and "form of combating transnational crime" are given. It is stated that the problem of the existence and expansion of transnational crime in the form of shadow illegal activities of criminal organizations is one of the greatest threats of our time. It is stated that in connection with the commission of illegal acts by members of transnational criminal organizations of various orientations, the definition of the essence and content of this socially dangerous phenomenon is a non-trivial matter. It is emphasized that the modern scientific community reflects the desire to clearly establish and specify the current methods of combating transnational crime and to implement their appropriate classification. It is noted that both domestic and foreign scholars in the field of law classify methods of combating transnational crime according to a set of different criteria and factors. Scholars also emphasize the importance of intensifying effective international cooperation in this area.
\end{abstract}

10.15408/jch.v9i2.21661

Keywords: Form; Method; Transnational Crime; International Cooperation; Criminal Organization

* Received: March 17, 2021, revised: April 21, 2021, accepted: June 18, 2021, Published: 31 August, 2021.

${ }^{1} \mathrm{PhD}$ in Law, Associative Professor, Donetsk Law Institute of the Ministry of Internal Affairs of Ukraine (Donetsk, Ukraine). ORCID: https://orcid.org/0000-0003-1053-9758.

2 Doctor of Law, Professor, Honored Worker of Science and Technology of Ukraine, Professor the Department of Criminology and Criminal-Executive Law Chair of the National Academy of Internal Affairs Kyiv (Kyiv, Ukraine). ORCID: https://orcid.org/0000-0002-8402-061X.

3 Doctor of Jurisprudence, Professor, Professor of Criminal Procedure, Criminalistics and Expertology Department of Kharkiv National University of Internal Affairs (Kharkiv, Ukraine). ORCID: https://orcid.org/0000-0002-3379-5036

${ }^{4}$ Candidate of Law, Associate Professor, Professor of the Department of Criminal Law and Criminology of Odessa State University of Internal Affairs (Odessa, Ukraine). ORCID: https://orcid.org/00000002-3223-2194.

Corresponding author: pchelkinv@ukr.net 


\title{
Menilai Isu Kontemporer Melawan Kejahatan Transnasional
}

\begin{abstract}
Abstrak
Kejahatan selalu dianggap sebagai sesuatu yang tak terelakkan dalam setiap masyarakat yang beroperasi di bawah sistem operasi yang terorganisir. Terkadang kejahatan ini harus melintasi batas negara yang merupakan ancaman besar bagi kedaulatan dan keutuhan negara. Dengan semua ini, Negara biasanya dihadapkan pada kemungkinan bentuk dan metode untuk memerangi apa yang disebut kejahatan transnasional. Contoh-contoh spesifik dari pengalaman sukses negara-negara maju, seperti Amerika Serikat, Kanada dan negaranegara Eropa Barat, dianalisis. Definisi penulis tentang istilah "kejahatan transnasional", "metode pemberantasan kejahatan transnasional" dan "bentuk pemberantasan kejahatan transnasional" diberikan. Disebutkan bahwa masalah keberadaan dan perluasan kejahatan transnasional berupa kegiatan ilegal bayangan organisasi kriminal merupakan salah satu ancaman terbesar di zaman kita. Disebutkan bahwa sehubungan dengan dilakukannya perbuatan melawan hukum yang dilakukan oleh anggota organisasi kriminal lintas negara dari berbagai orientasi, maka pengertian esensi dan isi dari fenomena bahaya sosial ini bukanlah hal yang sepele. Ditekankan bahwa komunitas ilmiah modern mencerminkan keinginan untuk secara jelas menetapkan dan menentukan metode terkini untuk memerangi kejahatan transnasional dan untuk menerapkan klasifikasi yang sesuai. Perlu dicatat bahwa baik sarjana dalam dan luar negeri di bidang hukum mengklasifikasikan metode memerangi kejahatan transnasional menurut seperangkat kriteria dan faktor yang berbeda. Para ahli juga menekankan pentingnya mengintensifkan kerja sama internasional yang efektif di bidang ini.
\end{abstract}

Kata kunci: Bentuk; Metode; Kejahatan Lintas Negara; Kerjasama internasional; Organisasi Kriminal

\section{Оценка Современных Проблем Противодействия Транснациональной Преступности}

\begin{abstract}
Аннатация
Преступления всегда считаются неизбежными в каждом обществе, действующем в рамках организованной системы действий. Иногда это преступление должно пересекать границы, представляя огромную угрозу суверенитету и целостности страны. При наличии всего этого государства обычно сталкиваются с проблемой установления возможных форм и методов борьбы с так называемыми транснациональными преступлениями. Анализируются конкретные примеры успешного опыта развитых стран, таких как США, Канада и страны Западной Европы. Даны авторские определения терминов «транснациональная преступность», «метод борьбы с транснациональной преступностью» и «форма борьбы с транснациональной преступностью». Констатируется, что проблема существования и распространения транснациональной преступности в виде теневой противоправной деятельности преступных организаций является одной из самых серьезных угроз современности. В связи с совершением противоправных действий членами транснациональных преступных организаций различной направленности определение сущности и содержания этого общественно опасного явления является нетривиальным вопросом. Подчеркивается, что современное научное сообщество отражает стремление четко установить и конкретизировать существующие методы борьбы с транснациональной преступностью и внедрить их соответствующую классификацию. Отмечается, что как отечественные, так и зарубежные ученые в области права классифицируют методы борьбы с транснациональной преступностью по набору различных критериев и факторов. Ученые также подчеркивают важность активизации эфффективного международного сотрудничества в этой области.
\end{abstract}

Ключевые слова: форма, метод, транснациональная преступность, международное сотрудничество, преступная организация. 


\section{A. INTRODUCTION}

The first attempts to counter such a socially dangerous phenomenon as transnational crime appeared almost simultaneously with the emergence of transnational crime itself. It is logical that over time, these methods gradually improved, becoming more complex. Of course, the improvements in the countering transnational crime methods took place rather in a forced manner. This was due to the constant progress of criminals and criminal organizations in the ways and methods of committing their illegal acts.

Transnational crime became more and more complicated from year to year and took place under cover of more secret criminal acts. That is why, in order to detect and investigate such complex crimes, investigators, as well as all other entities involved in the investigation of crimes and countering transnational crime, need to constantly improve the forms and methods of law enforcement.

Transnational organized crime and corruption are among the main threats to state security. It is no secret that foreign secret services are actively using this direction to destabilize the situation in Ukraine. They even try to infiltrate the authorities and take control of certain sectors of the economy and public administration. According to the Security Service of Ukraine, in 2020 more than 500 corrupt practices were blocked, which made it possible to prevent billions in losses for the state. In addition, the Security Service conducted special operations to counter international smugglers. For example, a record consignment of tobacco products worth 120 million hryvnias was seized. Also, blocking the activities of a powerful transnational drug group "Khimprom" is among the achievements (Countering transnational organized crime, 2021).

As we can see, in today's conditions the problem of counterting transnational organized crime is extremely relevant both by the scientists, public and by law enforcement agencies. This is due to the fact that it is one of the most dangerous forms of organized crime, which controls a significant part of capital, illegal activities related to legalization (laundering) of proceeds from crime, tax evasion, smuggling, etc.

The issues of the article is extremely serious and relevant not only for the domestic society, but also for most countries. In particular, this applies to the most powerful and developed states of our day.

Given the above, the purpose of this article is to identify, analyze and classify modern forms and methods of countering transnational crime. 
Moreover, this refers to the current state of affairs in this area both in Ukraine and in other countries.

\section{B. METHODS}

Research methods were selected taking into account the specifics of the subject of scientific research. In the article, the authors used the dialectical method of cognition of reality, general scientific and special research methods. Using the dialectical method, methodological and general theoretical approaches to defining the concepts of "transnational crime", "method of combating transnational crime" and "form of combating transnational crime" are determined, as well as conclusions and proposals on the topic of the article are formulated. Methods of formal logic are used to study scientific sources on issues included in the subject of research, regulatory legal acts. The systemicstructural method made it possible to determine a system of promising forms and methods of countering transnational crime. Using the comparative legal method, the author analyzes the provisions of international and national legislation regulating the issues of combating transnational crime. Also, using the comparative legal method, specific examples of the successful experience of the developed countries of the world, such as the USA, Canada and Western European states, have been analyzed. The situation here is that with all these analyses experienced in the various countries under examination, the notion of transnational crimes has not been able in combatting at all it levels, these countries continue to face difficulties when it comes to such crime despite all its efforts in combatting them. But from the above analysis, it is fundamental for us in establishing truly whether the concept of transnational crimes constitutes a threat to States security.

\section{RESULTS AND DISCUSSION}

Starting our study, we will quote Kofi Annan, UN Secretary-General, who stressed in his speech (United Nations Convention Against Transnational Organized Crime and the Protocols Thereto, 2004):

«If crime crosses borders, so must law enforcement. If the rule of law is undermined not only in one country, but in many, then those who defend it cannot limit themselves to purely national means. If the enemies of progress and human rights seek to exploit the openness and opportunities of globalization for their purposes, then we must exploit those very same factors to defend human 
rights and defeat the forces of crime, corruption and trafficking in human beings».

The problem of countering transnational crime is one of the most relevant and, accordingly, quite important and difficult for humanity and the states of the world community. Transnational crime threatens the very existence of the international community itself, as organized and purposeful criminal groups now exist in the structure of human society. They hinder the implementation not only of legal, but also of interstate socio-economic policy in general. Organized interstate criminal groups commit the most dangerous illegal actions, including violent ones, encroach on the rights and freedoms of citizens, undermine the economy and law and order in the countries of the world and in the bodies of state power in various countries, in the activities of the UN, its formations, and other international organizations. Today, this circumstance is of paramount importance for the world community in countering transnational crime in the interests of international security and is even related to the problem of human survival (Bilenchuk et al, 2011, p. 12). It is in our country that corruption and politics, crime and economics, national interests have created a global model of transnational crime, understanding the origins and state of which should be considered a current problem of both national and world criminology. In Ukraine, transnational crime, perhaps for the first time in world practice, has proven its ability not only to pose a threat to national security, but to implement this threat in practice: to change borders, occupy large areas by military force, claim political leadership and demand recognition as full-fledged subjects of international law (Zharovska, 2014, p. 33).

Numerous practices of countering transnational crime convincingly prove that criminals involved in this area are not limited to one type of crime, but specialize in many at once. Thus, money from cybercrime, counterfeiting, trafficking in stolen art finance terrorist activities, human trafficking, etc. (Tatsiienko, 2018, p. 244).

Researching and analyzing modern forms and methods of countering transnational crime, which are currently taking place both in Ukraine and in the world as a whole, it is worth paying attention to where and how they were formed. In particular, the development of processes related to the countering transnational crime has been closely linked to the development of transnational crime itself. At the same time, it is impossible to ignore such an important element of countering this crime as the level of ability of state and public institutions in a particular state to effectively counter criminal acts (Smeulers \& Grunfeld, 2011). Thus, forming from the common opinions of different scholars 
a brief description of their views on this issue, we can say that there is a proven direct link between the efficiency and transparency of government agencies and institutions and the level of crime in a particular state.

To confirm these theses, the United States of America and some Western European countries, which have long demonstrated a fairly high efficiency of their activities, could be taken as an example. In particular, despite the fact that the existence and some aspects of the criminal activities of the Italian mafia ("Cosa Nostra") in the United States are well known throughout the world due to the cultural phenomenon of this phenomenon, which consisted in the dedication of many literary works and films to the mafia, in fact the so-called "power" of organized crime in the United States has never been significant, and its "peak" did not last long.

Due to the development of state institutions and public relations in this country, the dominance of organized crime in some new areas of business has been effectively eliminated. That is, American researchers note that every activity of criminal organizations in the United States, associated with the receipt of illicit profits from crimes or fraud in a particular economic sphere, was inevitably exposed and effectively eliminated (Cassese, 2002). In particular, both the construction business of the mafia in major cities in the North-East of the country and the gambling business in the West suffered the same fate. A concrete example of the direct link between the development of social and legal institutions of the state and the development of organized crime is the history of the development of gambling in Las Vegas in the middle and second half of XX century.

At first, taking advantage of the fact that the above-mentioned city at first was only small and, as it seemed then, unpromising, and therefore did not have a sufficient level of protection and control from the state and its organs, representatives of organized crime began to build gambling establishments there. The construction was carried out with money previously received by various criminal means. And during the first 15-20 years, this mafia business really experienced its heyday. However, subsequently, in connection with the obtaining of the city of Las Vegas the status of the world famous center of the gaming and entertainment industry, as well as in connection with the increase in the financial importance of this city, government agencies and institutions were developed there.

Since the attention of the world was upon Las Vegas, its operation has been closely monitored by United States law enforcement. The result of their work was the exposure of criminal schemes and machinations related to the 
activities of the gambling business and related institutions and their further liquidation or reorganization in a lawful manner.

Beginning in the 60s of the XX century, active counteraction to crime in the gambling business actively continued for about one decade and already in the early 80 s, there were almost no hotels or casinos associated with organized crime in Las Vegas (Smeulers, 2019).

In accordance with Part 2 of Art. 3 of the UN Convention against Transnational Organized Crime of 15.11.2000 (ratified by Ukraine on 04.02.2004), an offence is transnational in nature if:

1) It is committed in more than one State;

2) It is committed in one State but a substantial part of its preparation, planning, direction or control takes place in another State;

3) It is committed in one State but involves an organized criminal group that engages in criminal activities in more than one State;

4) It is committed in one State but has substantial effects in another State.

This Convention contains an approximate list of crimes that fall under this definition, namely:

1) Participation in an organized criminal group (Article 5 of the Convention);

2) Money laundering (Article 6 of the Convention);

3) Corruption (Article 8 of the Convention);

4) Obstruction of justice (Article 23 of the Convention).

Thus, as V. I. Shkurko (2019, p. 105) noted, the list of these illegal acts is not exhaustive, because the development and complication of social relations leads both to the complication and diversification of forms and methods of committing offenses, and to the emergence of new types.

In this regard, we support the opinion that the call of all nations of the world to substantially update the United Nations Convention against Transnational Economic Crime of 15 November 2000 to include crimes that are now recognized by the international community as transnational economic crimes is relevant nowadays. These are primarily crimes such as smuggling and cyberterrorism. Ideally, the goal should be to create an appropriate international legal act that covers all areas of the fight against transnational 
economic crime. Also, such a single legal act should be adopted at the level of the EU and other intergovernmental associations (Tatsiienko, 2018, p. 247).

This is very important for every democratic state governed by the rule of law. This is primarily due to the fact that the key to effective combating organized crime and other phenomena that accompany it and contribute to its development is the existence of stable and systemic legislation that should correspond to modern socio-political and socio-economic realities, as well as international practices in sphere of counteraction to transnational organized crime (Bakhurynska, 2020, p. 305).

In our opinion, the problem of countering transnational crime in Ukraine is not the lack of sufficient law enforcement agencies to combat it, or insufficient public attention to this problem. In fact, the problem is the weakness and inability of domestic state institutions to effectively address the current challenges and threats posed by transnational crime. Among other things, using recent research by Western authors, we can emphasize the growing role of the high-tech sector in the activities of transnational criminal groups.

The presence of modern means of conducting cyber operations of various directions in law enforcement agencies and divisions of Ukraine would make it possible to effectively counteract the commission of crimes by representatives of international organized crime syndicates, most of which are committed through the Internet, as well as computer, digital and information tools. In order to achieve a more significant process in the development of these high technologies, the domestic government, as well as local communities, need to work fruitfully with foreign governmental and private organizations. In particular, it is useful to attract on a temporary basis a number of experienced and highly qualified foreign specialists.

The closest and most productive cooperation should be organized with the representatives of developed and democratic countries of Western Europe and North America. Indeed, according to analyzes and research conducted in recent years, these states have the highest level of effectiveness in countering transnational criminal organizations of different directions. Their effectiveness, as practice shows, is achieved through the integrated use of modern technological devices, the most appropriate and effective methods of operational activities, clear and unambiguous legal regulation of such activities. Indeed, it is an indisputable fact that the example of a number of Western countries confirms that it is appropriate and rational to ensure the functioning of law enforcement agencies that counter the manifestations of transnational 
crime in the regulations of the state is an extremely useful element (Rabasa et al., 2017). Therefore, international cooperation is very important.

The specificity of international cooperation and law enforcement in countering organized crime is that it is carried out in two closely interrelated areas - countering organized crime and countering corruption. This, in turn, leads to the expansion of the scope of partnerships and broader compared to other areas of law enforcement interaction with international political organizations, focused on supporting the system of good governance and virtue (Rudoi, 2015, p. 143).

Nowadays, the primary problem of legal regulation of law enforcement agencies that are at the forefront of countering transnational crime is to determine the jurisdiction of each of these agencies. Namely, it is emphasized that each of the law enforcement agencies must have its own clear jurisdiction for specific types of crimes, or for specific protected areas of public life, which the law enforcement agency must protect against unlawful encroachments.

It is worth noting that issues related to jurisdiction appeared in the domestic, socio-political space especially acutely after the events of the Revolution of Dignity. Since then, several new and independent law enforcement agencies have appeared in Ukraine, such as the National AntiCorruption Bureau of Ukraine, the State Bureau of Investigation, and the Specialized Anti-Corruption Prosecutor's Office. Moreover, large-scale reforms of the departments already existing at that time were carried out. First of all, we are talking about the reform in the system of the Ministry of Internal Affairs, one of the key elements of which was the transformation of the militia into the police in 2015, the removal of the Minister of Internal Affairs from the functions of the operational leadership of the National Police, etc.

Most jurists and experts in the field of countering transnational crime agree that the definition of a clear and unambiguous jurisdiction of each of the currently existing law enforcement agencies is an extremely important task of the state and political leadership of the country and it should be resolved as soon as possible. Otherwise, given the rapid progress of transnational criminal organizations, it will be more difficult to counter them.

In the United States, the problem of introducing and supporting the active fight against transnational crime has even forced the US government to create and publish the "Strategy to Combat Transnational Crime" (On July 25, 2011). Some of the best specialists in the field of countering international crime have worked on the creation of this strategy. For example, there are people 
among them who for years have played a leading role in overcoming transnational criminal schemes of various orientations in the most dangerous parts of the world. Despite the fact that this Strategy is regularly updated, optimized and supplemented, several key elements remain unchanged. These elements are the specific forms and methods of countering transnational crime in the current context.

So, if we consider them, we can say that all these methods can be placed in several groups on the basis of their orientation. The first group of methods is actually the classic elements of law enforcement, namely the investigation of crimes, detection and neutralization of existing criminal schemes, witness protection and support for public prosecution of persons who committed crimes in transnational criminal organizations, or assisted in such commission.

The second group of forms and methods of counteraction is to ensure active and fruitful interaction with key US allies and partners in a given region. In particular, the US government plays an active role in helping allies to eliminate corruption in their own countries, providing partners with logistical, financial and other useful assistance.

The third group of methods is combined with a common emphasis on the so-called "economic" factors of transnational crime. That is, these methods include neutralizing the elements through which transnational criminal organizations can consolidate and develop in a given society. Such factors include corruption, bribery, fraud, bribery of government officials and politicians, systematic tax evasion schemes, opening secret bank accounts as sources for financing further criminal activity, money laundering, etc.

Western analysts argue that the delivery of accented "blows" precisely to the economic side of the activities of a particular transnational criminal organization is one of the most effective methods of its destruction. But either way, in one way or another, money and financial position are often both the main stimulus for the activities of criminal organizations and a key factor in their stability and ability to continue functioning.

The seizure of bank accounts of individuals and legal entities associated with the activities of international criminal organizations, the confiscation of criminally obtained money in favor of the state or victims, the imposition of targeted sanctions on criminals and their accomplices make a key contribution to combating crime. Namely, they significantly reduce the desire of criminals to participate in further crimes. 
The fourth group of methods is that the law enforcement agencies of the state should concentrate their leading efforts on those transnational criminal groups that pose the greatest danger to the state and society at the moment.

American experts explain this strategy by the fact that it allows to successfully solve several tasks that are constantly faced by law enforcement. First, by neutralizing the most dangerous criminal organization at the moment, law enforcement officers thereby eliminate significant potential threats from its future activities. Second, the successful neutralization of a serious and large transnational criminal organization will send a kind of signal to smaller ones that their activities are dangerous to themselves and they are likely take full criminal and civil responsibility for their criminal actions.

The fifth group of methods aims to significantly improve the interaction between all actors in countering transnational crime, both in the country and abroad. In form, this group of methods is similar to the second group of methods already considered in this article, which is used by the United States government.

However, there is a significant difference between them in terms of the object to which the effort is directed. Thus, the methods of the second group were to modernize relations with partner countries, create new allies in different regions of the world, to help them, that is, to work mostly with the governments of these countries. And the main task of the fifth group of methods is to find, invent and develop areas of fruitful interaction with members of the public (public associations and organizations that share common with Western society moral and political values), private entities and other actors.

Years of practical use of this group of methods confirm that indeed in some states fruitful cooperation with various elements of society brings more efficiency and effectiveness than formal relations with the governments of these states. Therefore, considering the main components of the above American strategy to counter transnational crime, we note that it, along with all its elements, is extremely relevant and effective. We believe that its implementation as a strategy of domestic law enforcement agencies will be useful and effective.

In the context of the above, we cite the opinion of N. Miniailo (2016, p. 124) that improving the national framework for combating organized crime, our state should proceed from the depth of the essence, the diversity of manifestations of organized crime, and not just from understanding it as a 
quantitative expression of crimes committed in connection with creation and activity of organized criminal groups.

\section{CONCLUSIONS}

Having summarized all the theses, statements and scientific views of various experts presented in this article, we can state that countering transnational crime is really one of the most important components of sustainable development and well-being of society and the state as a whole.

In order to successfully overcome such a socially dangerous problem as transnational crime, an effective strategy for overcoming it must be created and implemented. It is extremely important that each of the elements of the developed and implemented strategy is really actively applied in practice. It is known that the arbitrary attitude of civil servants and politicians to the legal norms and official state documents adopted by them, combined with the unscrupulous performance of their professional functions is the main problem that hindered the effective development of the state and society, including the countering transnational crime.

The attention of domestic officials, researchers and other representatives of society should be focused on the fact that a significant reduction in transnational crime is impossible without active and fruitful cooperation with other states. This is especially true for democratic and developed states with a real rule of law, which are leaders and leading actors not only in their regions, but throughout the world.

It is recommended to adapt to national legal and law enforcement realities the main provisions of the Strategy to Combat Transnational Organized Crime, adopted by the United States National Security Council, which provides for the use of modern and effective forms and methods of countering transnational crime which, when applied in a complex manner, are a powerful tool for neutralizing international criminal organizations and their schemes.

\section{REFERENCES:}

Bakhurynska, O. (2020). Some issues of improving the legislation in the field of combating organized crime. Business, Economics and Law. Number 2, 305309. 
Bilenchuk, P. D., Kofanov, A. V., Kobylianskyi, O. L. \& Paniotov, E. K. (2011). Transnational crime: forensic analysis. Monograph. Kyiv: KIY.

Cassese, A. (2002). The Rome Statute of the International Criminal Court: A Commentary / Editorial Board: A. Eser, G. Gaja, Ph. Kirsch, A. Pellet, B. Swart. New York: Oxford University Press.

Countering transnational organized crime. (2021). Official website of the Security Service of Ukraine. Retrieved from https://ssu.gov.ua/protydiiatransnatsionalnii-orhanizovanii-zlochynnosti (access date February 3, 2021)

Miniailo, N. (2016). International standards in the definition of organized crime. Visegrad Journal on Human Rights. Number 3, 124-129.

Rabasa, A., Schnaubelt, Ch., Chalk P. et al. (2017). Countering the Expansion of Transnational Criminal Networks. Santa Monica, Calif.: RAND Corporation.

Rudoi, K. N. (2015). Fight against transnational criminality as direction of providing of international safety organs of internal affairs of Ukraine. Scientific Bulletin of Kherson State University. Issue 4. Volume 2, 142-144.

Shkurko, V. I. (2019). Some issues of countering transnational crime as a threat to the world economy in the context of globalization. South Ukrainian Law Journal. Number 1, 104-108.

Smeulers, A. \& Grunfeld F. (2011). International Crimes and Other Gross Human Rights Violations. A Multi- and Interdisciplinary Textbook. Leiden, Boston: Martinus Nijhoff Publishers.

Smeulers, A. (2019). Why Serious International Crimes Might Not Seem «Manifestly Unlawful» to Low-level Perpetrators. Journal of International Criminal Justice. Number 17, 105-123.

Strategy to Combat Transnational Organized Crime. (On July 25, 2011). National Security Council / The White House President Barack Obama. Retrieved from https://obamawhitehouse.archives.gov/administration/eop/nsc/transnatio nal-crime (access date February 5, 2021)

Tatsiienko, V. (2018). The urgency of the study of countering transnational economic crime. Business, Economics and Law. Number 12, 244-242.

United Nations Convention Against Transnational Organized Crime and the Protocols Thereto. (2004). UNITED NATIONS. New York. Retrieved 
from

https://www.unodc.org/documents/middleeastandnorthafrica/organisedcrime/UNITED_NATIONS_CONVENTION_AGAINST_TRANSNATIO NAL_ORGANIZED_CRIME_AND_THE_PROTOCOLS_THERETO.pdf.

United Nations Convention against Transnational Organized Crime of 15 November 2000 (ratified by Ukraine on 4 February 2004). Official site of the Verkhovna Rada of Ukraine. URL: http://zakon.rada.gov.ua/laws/show/995_789 (access date February 1, 2021)

Zharovska, G. P. (2014). Transnational crime as a threat to national security of Ukraine. Scientific Bulletin of Uzhhorod National University. Series: Law. Issue 27. Volume 3, 33-37. 